\title{
The role of ethylene and 1-MCP in early-season sweet cherry 'Burlat' storage life
}

\author{
Manuel Joaquín Serradilla ${ }^{1,2 *}$, Natalia Falagán ${ }^{*}$, Barbara Bohmer ${ }^{1}$, Leon A. Terry ${ }^{1}$, \\ M.Carmen Alamar ${ }^{* *}$ \\ *Manuel Joaquín Serradilla and Natalia Falagán are joint first authors. \\ **Correspondence to M. Carmen Alamar, Cranfield University, Bedfordshire, UK, MK430AL. Email: m.d.alamargavidia@cranfield.a \\ c.uk \\ 1 Plant Science Laboratory, Cranfield University, Bedfordshire, UK, MK43 0AL. \\ 2 Área de Vegetales, Centro de Investigaciones Científicas y Tecnológicas de Extremadura,
}

Instituto Tecnológico Agroalimentario de Extremadura, Avenida Adolfo Suárez s/n - 06007Badajoz, Spain.

\begin{abstract}
Sweet cherries (Prunus avium L.) are highly appreciated because of their bioactive compound content and attractive organoleptic characteristics; however, they are very perishable. The aim of this work was to investigate whether ethylene and its antagonist 1-MCP affect the postharvest quality of an early-season sweet cherry cultivar, allowing storage life extension. 'Burlat' sweet cherries were subjected to three treatments at $1{ }^{\circ} \mathrm{C}$ for one month: i) control (air); ii) continuous ethylene supplementation $\left(10 \mu \mathrm{L} \mathrm{L}^{-1}\right)$; and iii) 1-Methylcyclopropene (1$\mathrm{MCP} ; 1 \mu \mathrm{L} \mathrm{L}^{-1}$ for $24 \mathrm{~h}$ ) followed by air. The incidence of postharvest physiological disorders, the evolution of physical and functional quality traits, and fruit senescence were evaluated at $0,7,14,21$, and 30 days. Results showed that sweet cherries were sensitive to both ethylene and 1-MCP treatments. Continuous ethylene exposure reduced abscisic acid accumulation, resulting in higher weight and firmness loss. Moreover, ethylene application decreased titratable acidity across the storage time, indicating an effect on sweet cherry senescence. No
\end{abstract}


significant differences among treatments were found for soluble solids content and individual sugars. Conversely, 1-MCP preserved firmness during the first 7 days of storage, while reduced the incidence of physiological disorders at the end of storage life. Furthermore, 1-MCP delayed the cyanidin-3-O-glucoside development for 7 days compared to control and ethylene treated cherries. Therefore, 1-MCP can be used to extend storage life of early-season sweet cherry.

Keywords: Prunus avium; Fruit quality; Disorders; Polyphenols; Sugars; Abscisic acid

\section{Introduction}

Sweet cherries are classified as non-climacteric fruit and, therefore, must be harvested at their optimum horticultural maturity for consumption (Serrano et al., 2005; Serradilla et al., 2011). Sweet cherry quality deterioration involves flesh softening, followed by skin colour changes and bruising, stem browning, fruit dehydration, and loss of acidity (Wang et al., 2016). These changes are especially severe in early cultivars such as 'Burlat'. This said, firmness is a critical quality factor to consider during processing and shipping (Zoffoli et al., 2017). It is well known that fruit softening is partially regulated by ethylene (Valero and Serrano, 2010; Iqbal et al., 2017); however, the impact of exogenous ethylene on non-climacteric fruit senescence remains unclear. Other plant growth regulators such as abscisic acid (ABA) may also control senescence (Luo et al., 2014). ABA is known to be responsible for modulating anthocyanin biosynthesis, which induces the colour changes occurred in sweet cherries during the second and third stages of growth (Teribia et al., 2016) and senescence during postharvest (Luo et al., 2014). 1-Methylcyclopropene (1-MCP), an ethylene antagonist, has been applied on apricots, peaches, nectarines, and plums (Lurie and Weksler, 2005) to enhance fruit storability by maintaining firmness (Blankenship and Dole, 2003). Yet, studies on the effect of 1-MCP on 
sweet cherry quality preservation, especially firmness, are scarce, and rather contradictory (Gong et al., 2002; Yang et al., 2011).

The aim of this work was to investigate the effect of 1-MCP as a postharvest technique to preserve the fruit quality of imported early-season sweet cherry 'Burlat', and the impact of exogenous ethylene on fruit senescence during cold storage.

\section{Materials and methods}

\subsection{Plant material}

Sweet cherries (Prunus avium L.) cultivar 'Burlat' were hand-picked from Jerte Valley (Agrupación de Cooperativas Valle del Jerte S.C.L., Spain) on the $4^{\text {th }}$ June 2016, at commercial maturity stage (score of 3 on the CTIFL colour chart). Once harvested, the fruit were placed in $5 \mathrm{~kg}$ macroperforated polypropylene bags and transported under commercial conditions (refrigerated lorry at $0 \pm 0.5^{\circ} \mathrm{C}$ ) to Cranfield University. The experiment started 3 days after harvest.

\subsection{Storage conditions}

Sound sweet cherry fruit on the stem (as $200 \mathrm{~g}$ polypropylene punnets) were placed into 12 Lock \& Lock 12 L (315 x 230 x 230 mm) polypropylene boxes (L \& Nordic OÜ, Estonia) in a cool room at $1 \pm 0.5{ }^{\circ} \mathrm{C}$ and $90 \pm 5 \%$ relative humidity $(\mathrm{RH})$ for 30 days. The following treatments were applied: i) continuous air (control); ii) continuous ethylene $\left(10 \mu \mathrm{L} \mathrm{L}^{-1}\right)$ (Amoah et al., 2017); iii) single 1-Methylcyclopropene (1-MCP) application (1 $\mu \mathrm{L} \mathrm{L}^{-1}$ for $\left.24 \mathrm{~h}\right)$ (Foukaraki et al., 2016) followed by air storage. The gas flow was controlled by mass flow controllers (Alicat Scientific, Tucson, USA), making use of a continuous flow of $350 \mathrm{~mL} \mathrm{~min}{ }^{-}$

1. The experimental design considered three biological replicates (punnets) per treatment. An initial evaluation was performed prior to postharvest storage (day 0 - three days of transit after 
harvest); further sampling points were taken at days 7, 14, 21 and 30. Thirty fruit per biological replicate and treatment were analysed at each evaluation day. Biochemical analysis were performed on freeze-dried samples, in triplicate.

\subsection{Physico-chemical parameters}

\section{Weight loss and fruit decay}

The weight of three individual punnets per treatment was recorded just before postharvest treatment application and storage (day zero) and at each sampling point thereafter, to calculate the weight loss according to Villalobos et al. (2014). Sweet cherry disorders and decay, such as fruit skin damage (cracking and ostiole-end splitting), mechanical damage or surface pitting, and fungal rot were visually assessed to determine their incidence (Villalobos et al., 2014).

\section{Objective colour and firmness}

Skin and flesh objective colour (lightness $\left[\mathrm{L}^{*}\right]$, chroma $\left[\mathrm{C}^{*}\right]$, and hue angle $\left[\mathrm{h}^{\circ}\right]$ ) was measured using a calibrated tristimulus colorimeter (Minolta Chroma Meter CIE 1976, model CR-400, Minolta Corp., Tokyo, Japan) with an $8 \mathrm{~mm}$ diameter viewing area and D65 illuminant.at four and two equidistant points, respectively. Firmness was measured on each evaluation day after $4 \mathrm{~h}$ at room temperature $\left(\mathrm{ca} .20^{\circ} \mathrm{C}\right)$ using a uniaxial testing machine (model 5542, Instron, Norwood, MA, USA) equipped with a calibrated $500 \mathrm{~N}$ cell. A $1 \mathrm{~mm}$ compressing force was applied with an $8 \mathrm{~mm}$ diameter probe to the equatorial area of each cherry at a speed of 100 $\mathrm{mm} \min ^{-1}$. Results were expressed as Newton (N) of maximal force (Alamar et al., 2017).

\section{Soluble solids content and titratable acidity}

Soluble solids content (SSC) were measured on the juice of ten cherries using an automatic temperature-compensated digital refractometer (model PR-32 $\alpha$, Atago Ltd., Tokyo, Japan), 
and the results reported as ${ }^{\circ}$ Brix. Titratable acidity (TA) was measured using an automatic titrator (Mettler Toledo Ltd., Leicester, UK); results were expressed as g malic acid $100 \mathrm{~mL}^{-1}$.

\subsection{Biochemical measurements}

\section{Individual sugars}

Sugars were analysed as described by Foukaraki et al. (2016). Fructose, glucose, and sucrose concentrations were determined using an Agilent 1200 series HPLC comprising a binary pump system Agilent, Wokingham, UK), equipped with a refractive index detector (RID, Agilent) G1362A and cooled autosampler set at $4{ }^{\circ} \mathrm{C}$. The sample extract $(20 \mu \mathrm{L})$ and standard mix sugar solution were injected into the HPLC system and eluted at $0.6 \mathrm{~mL} \mathrm{~min}^{-1}$ through a Rezex $\mathrm{RCM}$ monosaccharide $\mathrm{Ca}^{+}$size exclusion column of $300 \mathrm{~mm} \times 7.8 \mathrm{~mm}$ diameter, $8 \mu \mathrm{m}$ particle size (Phenomenex, Torrance, CA; part no. 00H-0130-K0) and with a Carbo- $\mathrm{Ca}^{2+}$ security guard cartridge of $4 \mathrm{~mm} \times 3 \mathrm{~mm}$ diameter (Phenomenex; part no. AJ0-4493). The presence and abundance of individual sugars were automatically calculated by comparison of extracts peak area with peak area of external standards $\left(0.05-2.5 \mathrm{mg} \mathrm{mL}^{-1}\right)$. Assays were performed in triplicate.

\section{Abscisic acid}

Abscisic acid (ABA) of was extracted from $100 \pm 0.5 \mathrm{mg}$ dw material using $6 \mathrm{~mL}$ of HPLC grade methanol:water:formic acid (75:20:5) solution. Seventy-five $\mu \mathrm{L}$ of labelled abscisic acid (d4-ABA) at $400 \mathrm{ng} \mathrm{mL}^{-1}$ was added at the beginning of the extraction process and used as internal standard. Samples were vortexed for $2 \mathrm{~min}$, incubated in ice for $1 \mathrm{~h}$, and centrifuged for $15 \mathrm{~min}$ at $4500 \mathrm{rpm}$ and $4{ }^{\circ} \mathrm{C}$. The supernatant was cleaned through a $0.2 \mu \mathrm{m}$ PTFE filter and evaporated overnight in the dark at $-95^{\circ} \mathrm{C}$ using a freeze dryer (Scanvac, Lynge, Denmark). Samples were then reconstituted with $400 \mu \mathrm{L}$ HPLC grade water:acetonitrile:formic acid 
mixture (90: 9.9:0.1), vortexed for $2 \mathrm{~min}$, transferred to $2 \mathrm{~mL}$ Eppendorf tubes and centrifuged for $2 \mathrm{~min}$ at $12100 \mathrm{rpm}$ at $4{ }^{\circ} \mathrm{C}$. Finally, the supernatant was filtered through $0.2 \mu \mathrm{m}$ PTFE filter and stored at $-40{ }^{\circ} \mathrm{C}$ until analysis. Endogenous ABA levels were quantified by using an Agilent 6540 Ultra High Definition Accurate Mass Q-TOF LC-MS System using a Dual ESI Agilent Jet Stream source in negative and positive mode (Agilent, Wokingham, UK), where the following settings were applied: nebulizer gas temperature $\left(\mathrm{N}_{2}\right) 200{ }^{\circ} \mathrm{C}$, at a flow rate of $8 \mathrm{~L}$ $\min ^{-1}$, sheath gas temperature $\left(\mathrm{N}_{2}\right) 350{ }^{\circ} \mathrm{C}$ at a flow rate of $11 \mathrm{~L} \mathrm{~min}^{-1}$. Five microliters of the reconstituted sample were considered for hormone quantification following Ordaz-Ortiz et al. (2015). Labelled and unlabelled ABA were purchased from National Research Council of Canada-Plant Biotechnology Institute.

\section{Individual phenolic compounds}

Freeze-dried powered samples $(150 \pm 0.5 \mathrm{mg} \mathrm{dw})$ were extracted and analysed according to Alamar and Terry (2013). Individual hydroxycinnamic acids, (neochlorogenic acid [NCA] and chlorogenic acid [CA]), flavan-3-ols (epicatechin [EP] and (+)-catechin [CAT]) and anthocyanins (cyanidin-3-glucoside [C-3-G] and cyanidin-3-riboside [C-3-R]) were quantified against external standards (Sigma-Aldrich, UK). A calibration curve (0.01-0.5 mg mL ${ }^{-1}$ ) was created for each compound.

\subsection{Statistical analysis}

Data were subjected to analysis of variance (ANOVA) using GenStat for Windows (10 ${ }^{\text {th }}$ version, VSN International Ltd., Herts., UK). The significant effect of the main factors (postharvest treatments and storage time), and their interactions, on the variables under study were evaluated at a $\mathrm{p}$-value $<0.05$, unless otherwise stated. Fisher least significant difference values (LSD) were calculated to separate means at a significance level of $5 \%$. 


\section{Results and discussion}

\subsection{1-MCP reduces the severity of storage disorders}

Currently, physiological disorders such as mechanical damage or pitting, bruising, and stem browning are a main challenge of sweet cherry supply chain, reducing consumer acceptance. It is well documented that softer fruit are more susceptible to pitting, leading to a shorter shelf life (Zoffoli et al., 2017). Loss of firmness also promotes decay. In this work, first sign of decay was observed at day 21 of storage (Fig. 1). Ethylene treated cherries reached the highest percentages (47\%) at 30 days of storage, followed by control cherries (45\%). At this time point, 1-MCP treated cherries showed lowest decay impact (30\%). The main injuries observed were shoulder depression and pedicel puncture impact damage. These results were in disagreement with Karagiannis et al. (2018), who found no significant changes at the pitting level between cherries treated with 1-MCP and control.

Generally, these disorders occur during harvesting and processing stages. In the study herein 1-MCP treatment was applied after processing plus three days of transport (transit between Spain and UK), showing a positive impact on injury incidence. Hence, these data suggested that an earlier application of 1-MCP (e.g. before processing) could further reduce susceptibility to mechanical damage and thereby improve the fruit cosmetic appearance.

\subsection{1-MCP preserves sweet cherry firmness during the first week of storage}

Weight loss reached significantly higher values for ethylene treated cherries at the end of storage when compared to control and 1-MCP fruit $(5.95 \%$ vs. $3.50 \%$ and $3.24 \%$ respectively), as shown in Fig. 2. This weight loss is related to firmness, as water allocation in the fruit, skin toughness, and cell wall modifications have been associated with fruit softening during ripening and senescence (Zoffoli et al., 2017). Firmness is one of the most valued quality 
attributes by consumers and industry (Esti et al., 2002), and a critical factor regarding storability (Zoffoli et al., 2017). In general, early cultivars such as 'Burlat' are much softer than late cultivars like 'Sweetheart' (e.g. $6.80 \mathrm{~N}$ vs. $23.63 \mathrm{~N}$ at commercial maturity respectively; Ballistreri et al., 2013). The results herein highlighted that 1-MCP treated fruit were significantly firmer after 7 days of cold storage $(1.9 \mathrm{~N})$ compared to control $(1.5 \mathrm{~N})$ and ethylene treated cherries (1.5 N; Fig. 3). This agreed with Wei et al. (2011) who reported that the application of 1-MCP in sweet cherry 'Summit' showed a positive effect on firmness at 0 ${ }^{\circ} \mathrm{C}$. However, in our study, the positive effect of $1-\mathrm{MCP}$ on firmness was limited to the first week of cold storage at $0{ }^{\circ} \mathrm{C}$, as reported by Karagiannis et al. (2018). No significant differences were found between control and ethylene treated fruit behaviour throughout storage life.

\subsection{1-MCP extends marketability based on external appearance}

Both skin and flesh colour parameters, such as $\mathrm{L}^{*}, \mathrm{C}^{*}$ and $\mathrm{h}^{\mathrm{o}}$ showed a significantly decreasing trend during cold storage in all cases (Fig. 4). The evolution of skin colour started from bright red mahogany to become full dark red mahogany. Hue angle was significantly higher for 1MCP treated cherries (21.54) compared to control fruit (18.18), during the first week of cold storage. Moreover, 1-MCP cherries had a more vivid colour (higher $\mathrm{C}^{*}$ ) than control and ethylene-treated fruit, for the first 15 days of storage. This skin darkening is associated with the quality loss and poorer consumer acceptance (Crisosto et al., 2003). The evolution of flesh colour was from red to dark red, showing 1-MCP treated cherries a less darkening of flesh (Fig. 4). Therefore, dark red to mahogany appearance is key to market cherries in UK (Wermund and Fearne, 2000).

It has been reported that cherries become redder and darker during cold storage due to the synthesis of anthocyanins (Correia et al., 2017). In this experiment, the primary anthocyanin at harvest was cyanidin-3-O-rutinoside $\left(1.85 \mathrm{~g} \mathrm{~kg}^{-1} \mathrm{dw}\right)$, followed by cyanidin-3-O-glucoside 
$\left(0.40 \mathrm{~g} \mathrm{~kg}^{-1} \mathrm{dw}\right)$. These findings were consistent with those reported by Ballistreri et al. (2013). For all treatments, cyanidin-3-O-rutinoside and cyanidin-3-O-glucoside concentrations increased during the first 7 days by $57 \%$ and $60 \%$ respectively, and then maintained the reached level throughout storage (Table 1). A similar response was reported by Gonçalves et al. (2004) for this same cultivar. Colour changes in cherries are strongly correlated to the anthocyanin accumulation during postharvest storage due to the impact of cold storage on the phenyalanine ammonia lyase (PAL) gene transcription and PAL enzyme activity (Tsaniklidis et al., 2017).

The significant effect of 1-MCP was only observed on cyanidin-3-O-glucoside at day 7 of cold storage, maintaining the concentration close to initial levels (Table 1). No significant effect was found among treatments for the other phenolic compounds analysed, demonstrating that the biosynthesis of hydroxycinnamic acids and flavan-3-ols in sweet cherries may not be regulated by the exogenous ethylene. (Table 1).

Apart from its external appearance, sweetness is one of the most determining characteristics in the consumer's repurchase of fresh cherries. Sweetness depends on sugar content, especially on the glucose and fructose ratio (Zoffoli et al., 2017). In this research work, SSC content was maintained throughout storage in all cases (between 12.4 and $14.2{ }^{\circ}$ Brix) and no significant interaction between time and treatment was found (Fig. 5). Generally, these small increases found at the end of storage are a consequence of dehydration (Remón et al., 2003). In terms of individual sugars, our results showed that glucose was the main sugar at harvest $\left(201.44 \mathrm{~g} \mathrm{~kg}^{-}\right.$ $\left.{ }^{1} \mathrm{dw}\right)$, followed by fructose (187.95 $\left.\mathrm{g} \mathrm{kg}^{-1} \mathrm{dw}\right)$ and sucrose $\left(16.90 \mathrm{~g} \mathrm{~kg}^{-1} \mathrm{dw}\right.$; Table 2). These findings agreed with Chockchaisawasdee et al. (2016) who reported that glucose and fructose predominate over sucrose. During storage, sucrose content decreased due to the degradation into simple sugars promoting the increase on glucose and fructose contents (Table 2). Although, no significant differences among treatments were found, 1-MCP treated cherries 
showed a slightly higher glucose and sucrose content, especially after 21 days of storage; whilst ethylene-treated cherries presented higher fructose concentration.

TA exhibited a significant decrease for all treatments, from $c a .0 .55 \mathrm{~g}$ malic acid $100 \mathrm{~mL}^{-1}$ at the beginning of storage to $c a .0 .30 \mathrm{~g}$ malic acid $100 \mathrm{~mL}^{-1}$ after 30 days at $1 \pm 0.5^{\circ} \mathrm{C}$ (Fig. 6.A), as previously found by Esti et al. (2002) and Yang et al. (2019). Ethylene-treated cherries showed the highest TA decrease during storage $(\mathrm{p}<0.05)$, when compared to control and 1MCP cherries (up to $53.72 \%$ ). With respect to $\mathrm{pH}$, values ranged from 4.0 to 4.4 (Fig. 6.B). Again, the highest values were observed in cherries treated with continuous ethylene supplementation, whilst 1-MCP treated cherries showed the lowest level throughout storage. Low pH values promote anthocyanin stability (Serradilla et al., 2011). These results evidenced an acceleration of senescence in ethylene-treated fruit, mainly after 21 days of cold storage, being the deadline for storage in ordinary atmosphere for this cultivar. This was because organic acids are considered the main respiratory substrates (Correia et al., 2017) and together with sugars, have a strong relationship with consumers' acceptability through the SSC/TA ratio (Crisosto et al., 2003). Thus, a high SSC/TA ratio ensures good eating quality and a repurchase by consumers based on its taste, but a shorter useful life (Zoffoli et al., 2017).

\subsection{Ethylene supplementation accelerates senescence in sweet cherry}

Maturation in non-climacteric fruit is not regulated by ethylene but through ABA (Ren et al., 2011), which may induce senescence metabolism in cherry fruit (Luo et al., 2014). However, this work has shown several sweet cherry responses to both ethylene and 1-MCP treatments. Endogenous ABA levels decreased throughout storage, regardless of treatment (Fig. 7). Tijero et al. (2016) also reported a decrease in ABA content in sweet cherry during cold storage at 4 ${ }^{\circ} \mathrm{C}$. Thus said, ABA content was significantly lower in ethylene-treated fruit $\left(0.001 \mathrm{~g} \mathrm{~kg}^{-1}\right)$ towards the end of storage (day 21) compared to control $\left(0.003 \mathrm{~g} \mathrm{~kg}^{-1}\right)$ and 1-MCP treated 
cherries $\left(0.002 \mathrm{~g} \mathrm{~kg}^{-1}\right)$. Therefore, ethylene may suppress the ABA biosynthesis (Fig. 7), preventing the closure of the stomata and in turn, increasing transpiration and weight loss (Daszkowska-Golec and Szarejko, 2013; Fig. 2). Conversely, Karagiannis et al. (2018) showed that the application of 1-MCP could induce ABA synthesis; yet no differences were found in the experiment herein. In general, cherries displaying higher ABA concentration, had also higher firmness and TA levels and lower weigh losses and disorders, which would be related to better consumer acceptance.

\section{Conclusions}

Early sweet cherry postharvest behaviour was affected by 1-MCP. Imported cherries exposed to a single 1-MCP application ( $1 \mu \mathrm{L} \mathrm{L}^{-1}$ for $24 \mathrm{~h}$, three days after harvest) slowed down senescence symptoms as demonstrated by the higher firmness, less loss of TA, and delay in skin darkening. These results would lead to better consumer acceptance and satisfaction. Concomitantly, postharvest continuous ethylene supplementation accelerated senescence in early season cultivar 'Burlat', having an effect mostly on fruit softening, TA loss, and abscisic acid metabolism. There is a potential industrial use for 1-MCP as a commercial postharvest treatment at packing houses in non-climacteric sweet cherry, extending its marketability.

\section{Acknowledgements}

The authors thank Agrupación de Cooperativas Valle del Jerte S.C.L. for providing fruit samples for this work. This work was supported by Consejería de Educación y Empleo de la Junta de Extremadura (MOV15A031; DOE $n^{\circ} 228$, de 8 de noviembre). Thanks are also due to Cranfield University for scientific support, and use of facilities and equipment.

\section{References}


Alamar M.C., Terry, L.A., 2013. Temporal changes in individual phenolics and sugars in imported nectarines subjected to simulated 'real world' supply chain conditions. Acta Hortic. 1012: 1291-1297. https://doi.org/10.17660/ActaHortic.2013.1012.173.

Alamar, M.C., Collings, E., Cools, K., Terry, L.A., 2017. Impact of controlled atmosphere scheduling on strawberry and imported avocado fruit. Postharvest Biol. Technol. 134, 7686. https://doi.org/10.1007/s00217-003-0789-x.

Amoah, R.S., Landahl, S., Terry, L.A., 2017. Design and construction of a flexible laboratory scale mixing apparatus for continuous ethylene supplementation of fresh produce. Biosys. Eng. 157, 86-91. doi.org/10.1016/j.biosystemseng.2017.02.010.

Ballistreri, G., Continella, A., Gentile, A., Amenta, M., Fabroni, S., Rapisarda, P., 2013. Fruit quality and bioactive compounds relevant to human health of sweet cherry (Prunus avium L.) cultivars grown in Italy. Food Chem. 140, 630-638. https://doi.org/10.1016/j.foodchem.2012.11.024.

Blankenship, S.M., Dole, J.M. 2003. 1-Methylcyclopropene: a review. Postharvest Biol. Technol. 28, 1-25. https://doi.org/10.1016/S0925-5214(02)00246-6

Chockchaisawasdee, S., Golding, J.B., Vuong, Q.V., Papoutsis, K., Stathopoulos, C.E., 2016. Sweet cherry: Composition, postharvest preservation, processing and trends for its future use. Trends Food Sci. Tech. 55, 72-83. https://doi.org/10.1016/j.tifs.2016.07.002.

Correia, S., Schouten, R., Silva, A.P., Gonçalves, B., 2017. Factors affecting quality and health promoting compounds during growth and postharvest life of sweet cherry (Prunus avium L.). Front. Plant Sci. 8, 2166. https://doi.org/10.3389/fpls.2017.02166.

Crisosto, C.H., Crisosto, G.M., Metheney, P., 2003. Consumer acceptance of 'Brooks' and 'Bing' cherries is mainly dependent on fruit SSC and visual skin colour. Postharvest Biol. Technol. 28, 150-167. 
Daszkowska-Golec, A., Szarejko I., 2013. Open or close the gate - stomata action under the control of phytohormones in drought stress conditions. Front. Plant Sci. 4, 138. https://doi.org/10.3389/fpls.2013.00138

Esti, M., Cinquanta, L., Sinesio, F., Moneta, E., Di Matteo, M., 2002. Physicochemical and sensory fruit characteristics of two sweet cherry cultivars after cool storage. Food Chem. 76(4), 399-405. https://doi.org/10.1016/S0308-8146(01)00231-X

Foukaraki, S.G., Cools, K., Chope, G.A., Terry, L.A., 2016. Impact of ethylene and 1-MCP on sprouting and sugar accumulation in stored potatoes. Postharvest Biol. Technol. 114, 95103. http://dx.doi.org/10.1016/j.postharvbio.2015.11.013.

Gonçalves, B., Landbo, A. K., Knudsen, D., Silva, A.P., Moutinho-Pereira, J., Rosa, E., Meyer, A.S., 2004. Effect of ripeness and postharvest storage on the phenolic profiles of cherries (Prunus avium L.). J. Agric. Food Chem. 52, 523-530.

Gong, Y., Fan, X., Mattheis, P., 2002. Responses of 'Bing' and 'Rainier' sweet cherries to Ethylene and 1-Methylcyclopropene. J. Am. Soc. Hortic. Sci. 127, 831-835.

Iqbal, N., Khan, N.A., Ferrante, A., Trivellini, A., Francini, A., Khan, M.I.R., 2017. Ethylene role in plant growth, development and senescence: Interaction with other phytohormones. Front. Plant Sci. 8, 475, 1-19. http://doi.org/ 10.3389/fpls.2017.00475

Karagiannis, E., Michailidis, M., Karamanoli, K., Lazaridou, A., Minas, I.S., Molassiotis, A., 2018. Postharvest responses of sweet cherry fruit and stem tissues revealed by metabolomic $\begin{array}{llll}\text { profiling. Plant } & \text { Physiol. } & \text { Biochem. } & \text { 127, }\end{array}$ https://doi.org/10.1016/j.plaphy.2018.04.029

Luo, H., Dai, S.J., Ren, J., Zhang, C.X., Ding, Y., Li, Z., Sun, Y., Ji, K., Wang, Y.P., Li, Q., Chen, P., Duan, C., Wang, Y., Leng, P., 2014. The role of ABA in the maturation and postharvest life of a nonclimacteric sweet cherry fruit. J. Plant Growth Regul. 33, 373-383. https://doi.org/10.1007/s00344-013-9388-7. 
Lurie, S., Weksler, A., 2005. Effects of 1-Methylcyclopropene on Stone Fruits. Acta Hortic. $682,85-90$.

Ordaz-Ortiz, J.J., Foukaraki, S., Terry, L.A., 2015. Assessing temporal flux of plant hormones in stored processing potatoes using high definition accurate mass spectrometry. Hortic. Res. 2, 15002. doi:10.1038/hortres.2015.2.

Remón, S., Venturini, M. E., Lopez-Buesa, P., Oria, R., 2003. 'Burlat' cherry quality after long range transport: optimisation of packaging conditions. Innovative Food Science \& Emerging Technologies, 4(4), 425-434. https://doi.org/10.1016/S1466-8564(03)00058-4.

Ren, J., Chen, P., Dai, S.J., Li, P., Li, Q., Ji, K., Wang, Y.P., Leng, P., 2011. Role of abscisic acid and ethylene in sweet cherry fruit maturation: molecular aspects. N. Z.1. J. Crop Hortic. Sci. 39(3), 161-174. https://doi.org/10.1080/01140671.2011.563424.

Serradilla, M.J., Lozano, M., Bernalte, M.J., Ayuso, M.C., López-Corrales, M., GonzálezGómez, D., 2011. Physicochemical and bioactive properties evolution during ripening of 'Ambrunés' sweet cherry cultivar. LWT. 44, 199-205. https://doi.org/10.1016/j.1wt.2010.05.036.

Serrano, M., Guillén, F., Martínez-Romero, D., Castillo, S., Valero, D., 2005. Chemical constituents and antioxidant activity of sweet cherry at different ripening stages. J. Agric. Food Chem. 53(7), 2741-2745. https://doi.org/10.1021/jf0479160.

Teribia, N., Tijero, V., Munné-Bosch, S., 2016. Linking hormonal profiles with variations in sugar and anthocyanin contents during the natural development and ripening of sweet cherries. New Biotechnol. 33(6), 824-833. https://doi.org/10.1016/j.nbt.2016.07.015.

Tijero, V., Teribia, N., Muñoz, P., Munné-Bosch, S., 2016. Implication of abscisic acid on ripening and quality in sweet cherries: differential effects during pre-and post-harvest. Front. Plant Sci. 7, 602. https://doi.org/10.3389/fpls.2016.00602 
Tsaniklidis, G., Kafkaletou, M., Delis, C., Tsantili, E., 2017. The effect of postharvest storage temperature on sweet cherry (Prunus avium L.) phenolic metabolism and colour development. Sci. Hortic. 225, 751-756. https://doi.org/10.1016/j.scienta.2017.08.017

Valero, D., Serrano, M., 2010. Postharvest biology and technology for preserving fruit quality. Boca Raton: CRC press.

Villalobos, M.C., Serradilla, M.J., Martín, A., Ruiz-Moyano, S., Pereira, C., Córdoba, M.G., 2014. Use of equilibrium modified atmosphere packaging for preservation of 'San Antonio' and 'Banane' breba crops (Ficus carica L.). Postharvest Biol. Technol. 98, 14-22. https://doi.org/10.1016/j.postharvbio.2014.07.001

Wang, L., Zhang, H., Jin, P., Guo, X., Li, Y., Fan, C., Wang, J., Zheng, Y., 2016. Enhancement of storage quality and antioxidant capacity of harvested sweet cherry fruit by immersion with b-aminobutyric acid. Postharvest Biol. Technol. 118, 71-78. https://doi.org/10.1016/j.postharvbio.2016.03.023.

Wei, J., Qi, X., Guan, J., Zhu, X., 2011. Effect of cold storage and 1-MCP treatment on postharvest changes of fruit quality and cell wall metabolism in sweet cherry. J. Food Agric. Environ. 9, 118-122.

Wermund, U., Fearne, A., 2000. Key challenges facing the cherry supply chain in the UK. Acta Hortic. 536, 613-624.

Yang, Q., Wang, L., Li, F., Ma, J., Zhang, Z., 2011. Impact of 1-MCP on postharvest quality of sweet cherry during cold storage. Front. Agri. China. 5(4), 631-636. https://doi.org/10.1007/s11703-011-1110-6.

Yang, Q., Zhang, X., Wang, F., Zhao Q., 2019. Effect of pressurized argon combined with controlled atmosphere on the postharvest quality and browning of sweet cherries. Postharvest Biol. Technol. 147, 59-67. https://doi.org/10.1016/j.postharvbio.2018.09.007. 
Zoffoli, J.P., Toivonen, P., Wang, Y., 2017. Postharvest Biology and Handling for Fresh Markets. Cherries: Botany, Production and Uses, 460-484. 


\section{Figures}

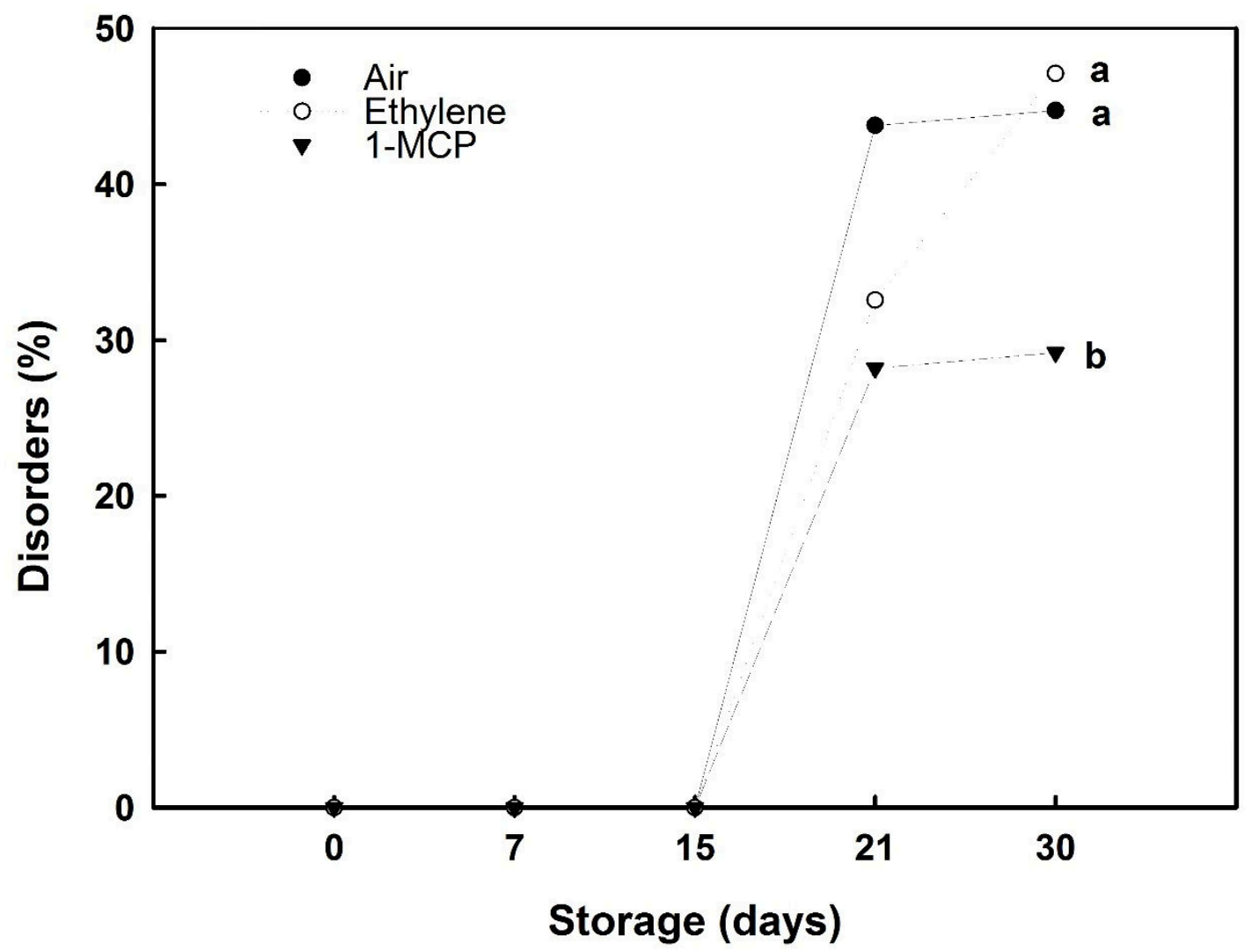

Fig. 1. Effect of postharvest treatments (air [control]; continuous ethylene supplementation [10 $\left.\mu \mathrm{L} \mathrm{L}^{-1}\right]$; and 1-MCP $\left[1 \mu \mathrm{L} \mathrm{L}^{-1}\right.$ for $24 \mathrm{~h}$ at room temperature followed by air $]$ ) on disorders (\%) in sweet cherry fruit 'Burlat' during 30 days storage at $1 \pm 0.5{ }^{\circ} \mathrm{C}$ and $90 \pm 5 \% \mathrm{RH}$. Data represent means. Letters represent significant differences $(p<0.05)$ for the interaction baseline * treatment * sampling day. 


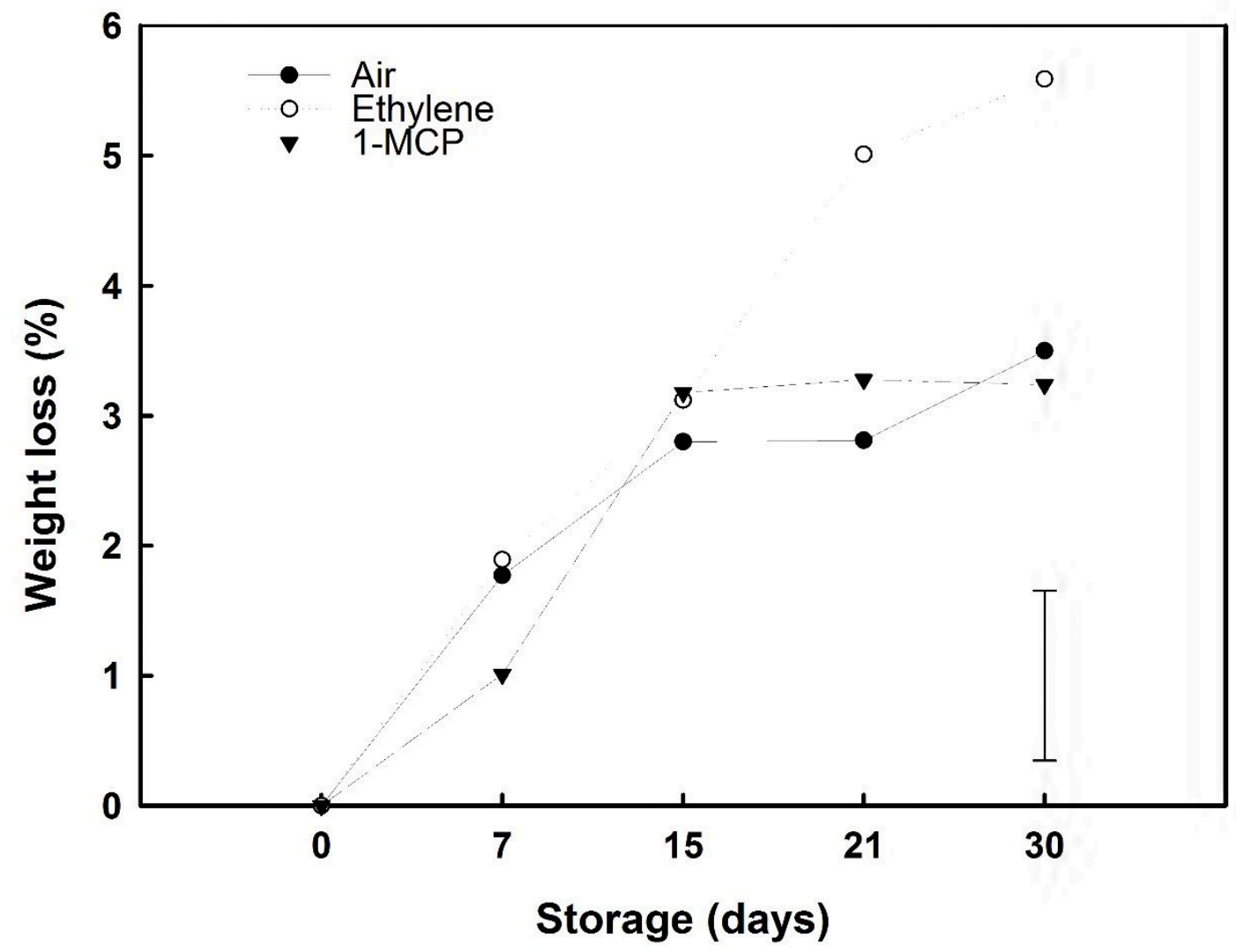

Fig. 2. Effect of postharvest treatments (air [control]; continuous ethylene supplementation [10 $\left.\mu \mathrm{L} \mathrm{L}^{-1}\right]$; and 1-MCP [1 $\mu \mathrm{L} \mathrm{L}^{-1}$ for $24 \mathrm{~h}$ at room temperature followed by air]) on weight loss (\%) in sweet cherry fruit 'Burlat' during 30 days storage at $1 \pm 0.5^{\circ} \mathrm{C}$ and $90 \pm 5 \%$ RH. Data represent means. Bars represent LSD $(\mathrm{p}<0.05)$ for the interaction baseline * treatment * sampling day. 


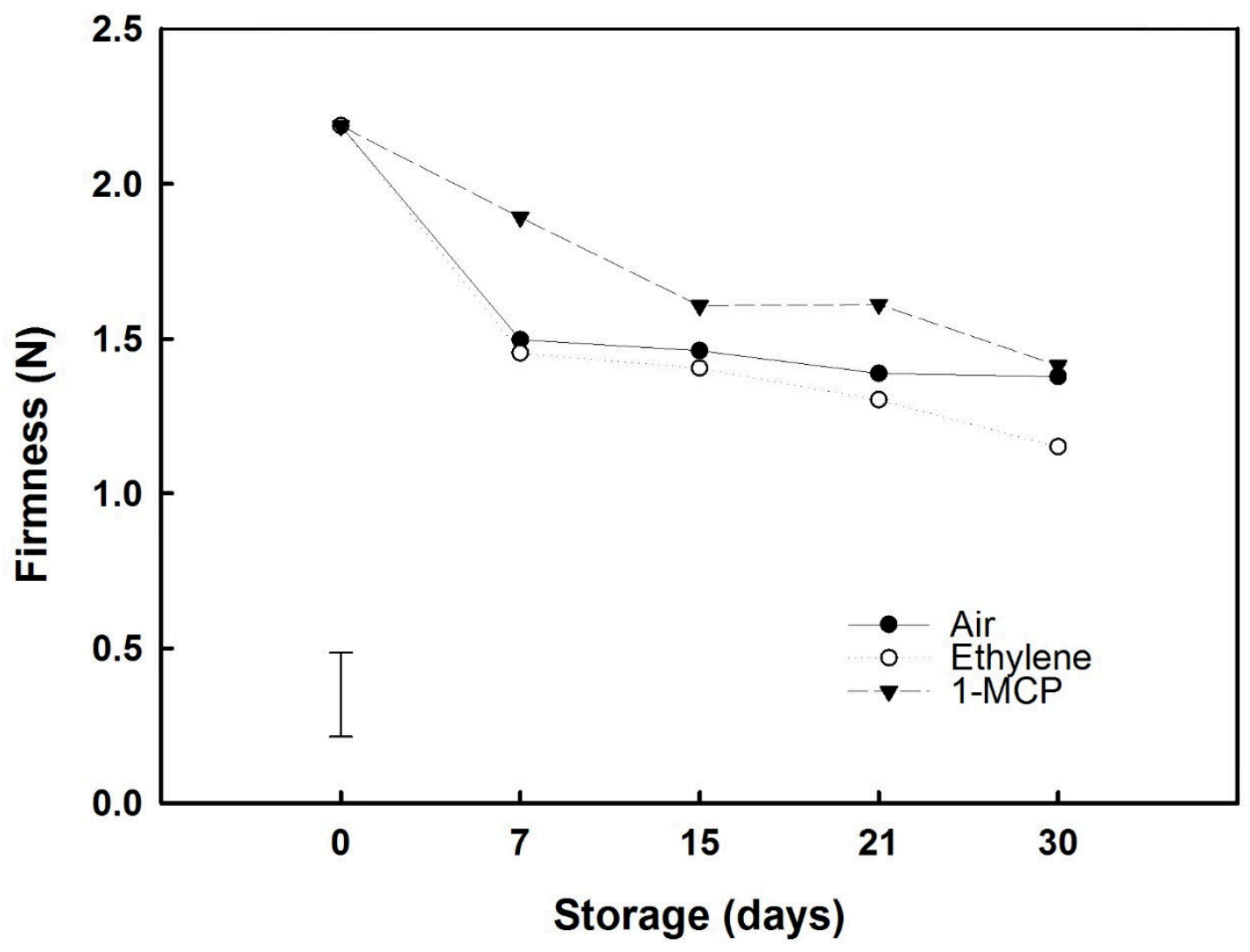

Fig. 3. Effect of postharvest treatments (air [control]; continuous ethylene supplementation [10 $\left.\mu \mathrm{L} \mathrm{L}^{-1}\right]$ ); and 1-MCP [1 $\mu \mathrm{L} \mathrm{L}^{-1}$ for $24 \mathrm{~h}$ at room temperature followed by continuous air]) on firmness $(\mathrm{N})$ in sweet cherry fruit 'Burlat' during 30 days storage at $1 \pm 0.5{ }^{\circ} \mathrm{C}$ and $90 \pm 5 \%$ RH. Data represent means. Bars represent LSD $(p<0.05)$ for the interaction baseline * treatment $*$ sampling day. 


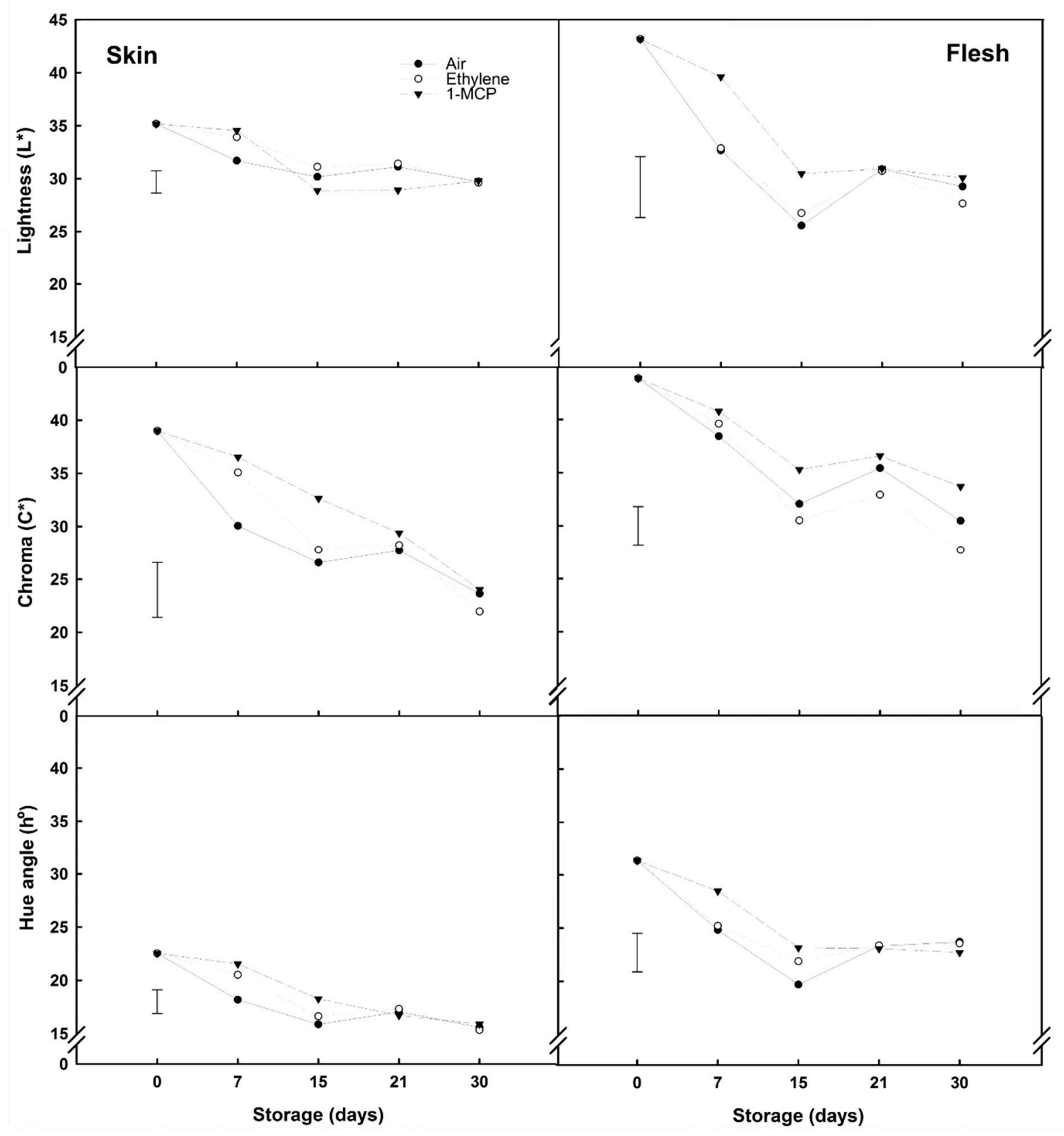

Fig. 4. Effect of postharvest treatments (air [control]; continuous ethylene supplementation [10 $\left.\mu \mathrm{L} \mathrm{L}^{-1}\right]$; and 1-MCP [1 $\mu \mathrm{L} \mathrm{L}^{-1}$ for $24 \mathrm{~h}$ at room temperature followed by air]) on skin (left) and flesh (right) objective colour (L* [lightness], $\mathrm{C}^{*}$ [chroma], $\mathrm{h}^{\mathrm{o}}$ [hue angle]) of sweet cherry fruit 'Burlat' during 30 days storage at $1 \pm 0.5{ }^{\circ} \mathrm{C}$ and $90 \pm 5 \% \mathrm{RH}$. Data represent means. Bars represent LSD $(\mathrm{p}<0.05)$ for the interaction baseline * treatment * sampling day. 


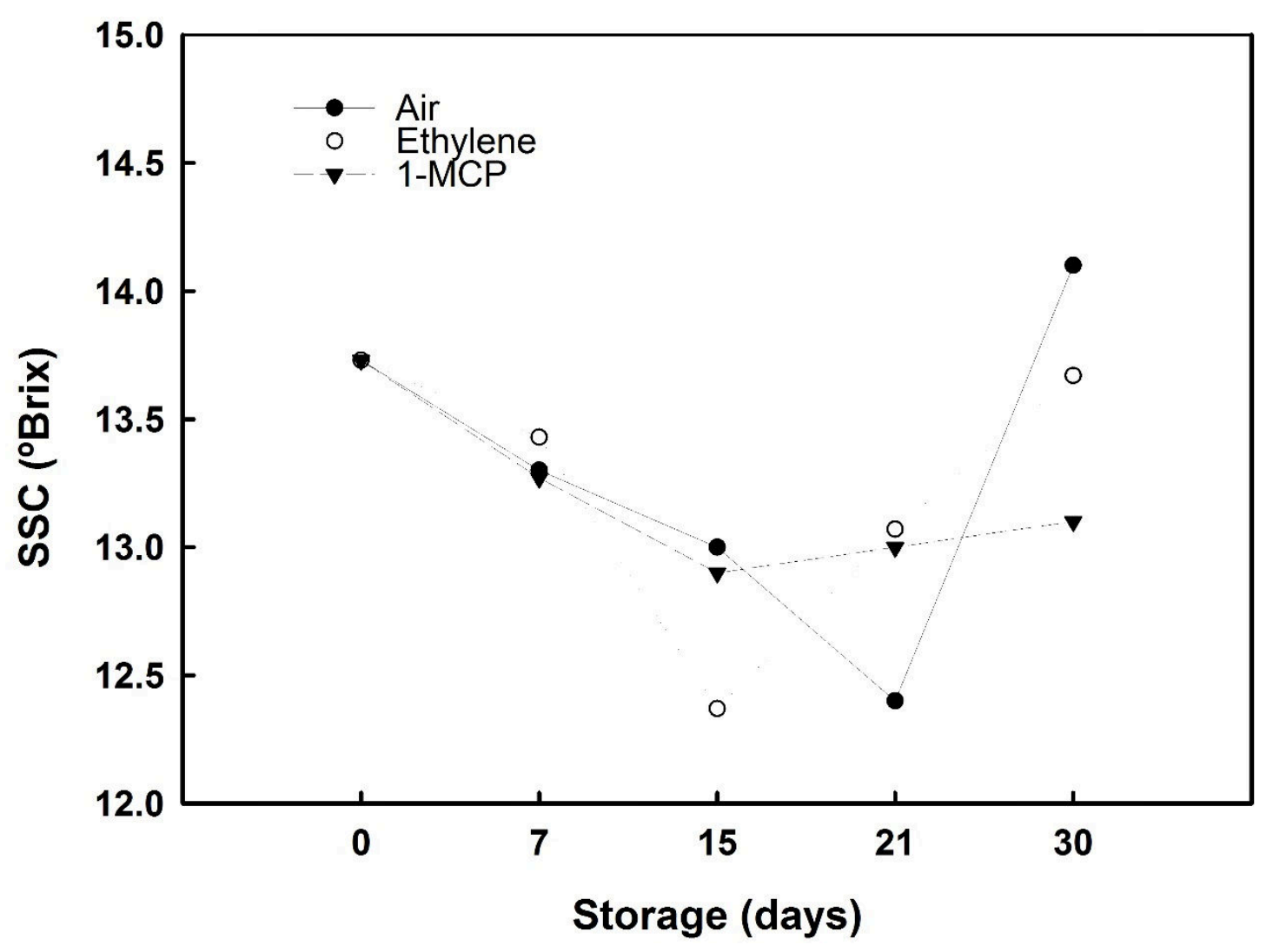

Fig. 5. Effect of postharvest treatments (air [control]; continuous ethylene supplementation [10 $\left.\mu \mathrm{L} \mathrm{L}^{-1}\right]$; and 1-MCP [1 $\mu \mathrm{L} \mathrm{L}^{-1}$ for $24 \mathrm{~h}$ at room temperature followed by air]) on soluble solids content ( $\left({ }^{\circ} \mathrm{Brix}\right)$ of sweet cherry fruit 'Burlat' during 30 days storage at $1 \pm 0.5{ }^{\circ} \mathrm{C}$ and $90 \pm 5$ $\%$ RH. Data represent means. No significant differences were found. 


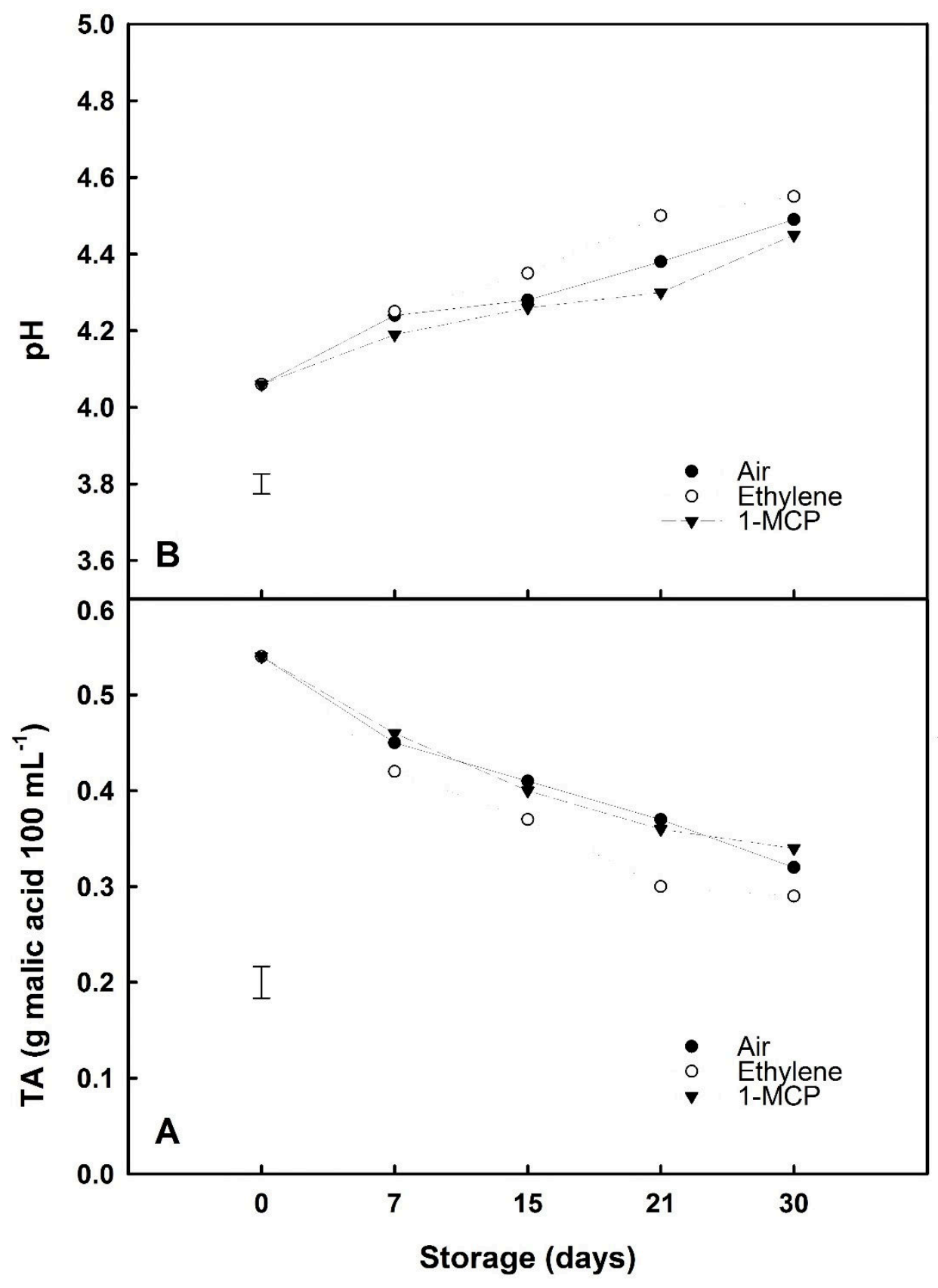

Fig. 6. Effect of postharvest treatments (air [control]; continuous ethylene supplementation [10 $\left.\mu \mathrm{L} \mathrm{L}^{-1}\right]$; and 1-MCP [1 $\mu \mathrm{L} \mathrm{L}^{-1}$ for $24 \mathrm{~h}$ at room temperature followed by air]) on: A. tritatable acidity (TA; g malic acid $100 \mathrm{~mL}^{-1}$ ) and $\mathrm{B}$. $\mathrm{pH}$. of sweet cherry fruit 'Burlat' during 30 days storage at $1 \pm 0.5^{\circ} \mathrm{C}$ and $90 \pm 5 \%$ RH. Data represent means. Bars represent LSD $(\mathrm{p}<0.05)$ for the interaction baseline * treatment * sampling day. 


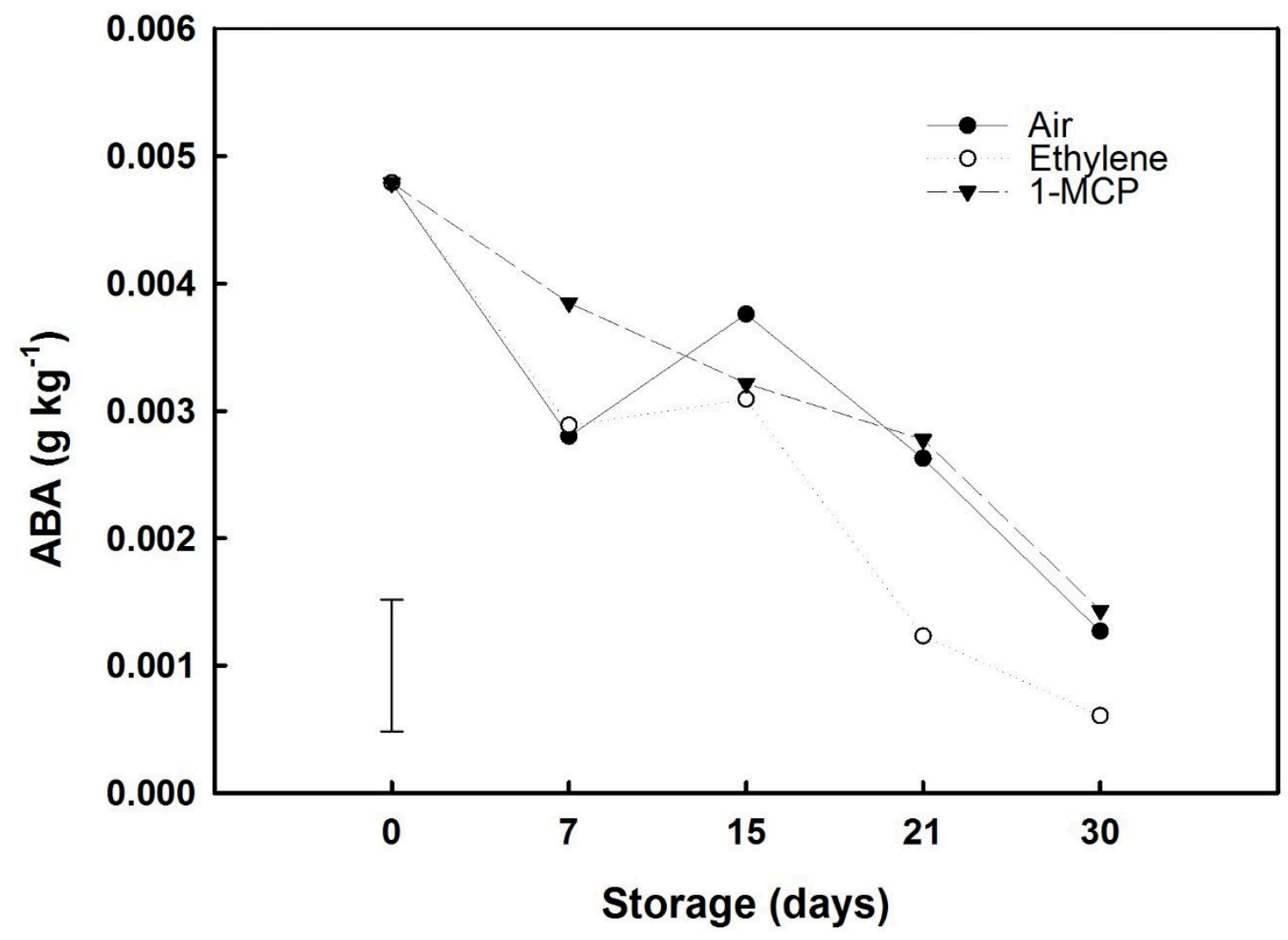

424 Fig. 7. Effect of postharvest treatments (air [control]; continuous ethylene supplementation [10 $\left.425 \mu \mathrm{L} \mathrm{L}^{-1}\right]$; and 1-MCP [1 $\mu \mathrm{L} \mathrm{L}^{-1}$ for $24 \mathrm{~h}$ at room temperature followed by air]) on abscisic acid 426 (ABA) content $\left(\mathrm{g} \mathrm{kg}^{-1} \mathrm{dw}\right)$ in sweet cherry fruit 'Burlat' during 30 days storage at $1 \pm 0.5^{\circ} \mathrm{C}$ 427 and $90 \pm 5 \%$ RH. Data represent means. Bars represent LSD $(\mathrm{p}<0.05)$ for the interaction 428 baseline $\mathrm{x}$ treatment $\times$ sampling day. Where baseline: prior to treatment application (day 0 ). 
431 Table 1. Mean values ( $\left.\mathrm{g} \mathrm{kg}^{-1} \mathrm{dw}\right)$ of individual phenolic compounds found in 'Burlat' cherries 432 at harvest and during cold storage at $1 \pm 0.5^{\circ} \mathrm{C}$ and $90 \pm 5 \% \mathrm{RH}$ after being subjected to three 433 different treatments: air (control); continuous ethylene supplementation $\left(10 \mu \mathrm{L} \mathrm{L}^{-1}\right)$; and 1$434 \mathrm{MCP}\left(1 \mu \mathrm{L} \mathrm{L}^{-1}\right.$ for $24 \mathrm{~h}$ at room temperature followed by continuous air). Least significant 435 differences at $5 \%\left(\operatorname{LSD}_{0.05}\right)$ for individual factors (viz. baseline and treatment) and the 436 interaction baseline * treatment * sampling point are shown. Where baseline: prior to treatment 437 application (day 0).

\begin{tabular}{|c|c|c|c|c|c|c|c|}
\hline & & \multicolumn{2}{|c|}{ Flavan-3-ols } & \multicolumn{2}{|c|}{$\begin{array}{c}\text { Hydroxycinnamic } \\
\text { acids }\end{array}$} & \multicolumn{2}{|c|}{ Anthocyanins } \\
\hline dates & Treatment & EP & CAT & NCA & $\mathrm{CA}$ & C-3-G & C-3-R \\
\hline $\begin{array}{l}\text { At harvest } \\
\text { (baseline) }\end{array}$ & & 0.66 & 1.02 & 1.19 & 0.42 & 0.40 & 1.85 \\
\hline Day7 & $\begin{array}{l}\text { Air } \\
\text { 1-MCP } \\
\text { Ethylene }\end{array}$ & $\begin{array}{l}0.65 \\
0.76 \\
0.75 \\
\end{array}$ & $\begin{array}{l}0.70 \\
0.79 \\
0.69 \\
\end{array}$ & $\begin{array}{l}1.36 \\
1.39 \\
1.29 \\
\end{array}$ & $\begin{array}{l}0.49 \\
0.50 \\
0.50 \\
\end{array}$ & $\begin{array}{l}1.02 \\
0.62 \\
0.89 \\
\end{array}$ & $\begin{array}{l}3.61 \\
3.09 \\
3.73 \\
\end{array}$ \\
\hline Day 15 & $\begin{array}{l}\text { Air } \\
\text { 1-MCP } \\
\text { Ethylene }\end{array}$ & $\begin{array}{l}0.79 \\
0.75 \\
0.69\end{array}$ & $\begin{array}{l}0.91 \\
0.75 \\
1.09 \\
\end{array}$ & $\begin{array}{l}1.33 \\
1.36 \\
1.30 \\
\end{array}$ & $\begin{array}{l}0.51 \\
0.51 \\
0.50\end{array}$ & $\begin{array}{l}1.31 \\
1.09 \\
0.95 \\
\end{array}$ & $\begin{array}{l}4.46 \\
3.82 \\
3.87 \\
\end{array}$ \\
\hline Day 21 & $\begin{array}{l}\text { Air } \\
\text { 1-MCP } \\
\text { Ethylene }\end{array}$ & $\begin{array}{l}0.74 \\
0.81 \\
0.80 \\
\end{array}$ & $\begin{array}{l}0.81 \\
0.77 \\
0.75 \\
\end{array}$ & $\begin{array}{l}1.47 \\
1.46 \\
1.47 \\
\end{array}$ & $\begin{array}{l}0.53 \\
0.53 \\
0.55\end{array}$ & $\begin{array}{l}0.90 \\
0.90 \\
0.96 \\
\end{array}$ & $\begin{array}{l}4.36 \\
4.34 \\
4.44 \\
\end{array}$ \\
\hline Day 30 & $\begin{array}{l}\text { Air } \\
\text { 1-MCP } \\
\text { Ethylene } \\
\end{array}$ & $\begin{array}{l}0.64 \\
0.95 \\
0.69 \\
\end{array}$ & $\begin{array}{l}0.72 \\
0.65 \\
0.94 \\
\end{array}$ & $\begin{array}{l}1.44 \\
1.52 \\
1.29 \\
\end{array}$ & $\begin{array}{l}0.50 \\
0.54 \\
0.48 \\
\end{array}$ & $\begin{array}{l}0.98 \\
1.16 \\
1.43 \\
\end{array}$ & $\begin{array}{l}4.99 \\
5.75 \\
5.00 \\
\end{array}$ \\
\hline $\begin{array}{l}\mathrm{LSD}_{0.05} \\
(\mathrm{~B} \times \mathrm{T} \times \mathrm{S})\end{array}$ & & 0.13 & 0.19 & 0.23 & 0.07 & NS & 1.02 \\
\hline
\end{tabular}

438 Where A: Scenario; B: Baseline; T: Treatment; S: sampling date; EP: epicatechin; CAT: $(+)-$ 439 catechin; NCA: neochlorogenic acid; CA: chlorogenic acid; C-3-G: cyanidin-3-O-glucoside; 440 C-3-R: cyanidin-3-rutinoside. 
443 Table 2. Mean values $\left(\mathrm{g} \mathrm{kg}^{-1} \mathrm{dw}\right)$ of individual sugars (viz. sucrose, glucose and fructose)

444 found in 'Burlat' sweet cherries at harvest and during cold storage at $1 \pm 0.5{ }^{\circ} \mathrm{C}$ and $90 \pm 5 \%$

445 RH after being subjected to three different treatments: air (control)]; continuous ethylene

446 supplementation $\left(10 \mu \mathrm{L} \mathrm{L}^{-1}\right)$; and 1-MCP $\left(1 \mu \mathrm{L} \mathrm{L}^{-1}\right.$ for $24 \mathrm{~h}$ at room temperature followed by

447 continuous air). Least significant differences at $5 \%\left(\mathrm{LSD}_{0.05}\right)$ for individual factors (viz.

448 baseline and treatment) and the interaction baseline * treatment $*$ sampling point are shown.

449 Where baseline: prior to treatment application (day 0).

\begin{tabular}{|l|l|l|l|l|}
\hline & & \multicolumn{3}{|c|}{ Sugars } \\
\hline Sampling dates & Treatment & Sucrose & Glucose & Fructose \\
\hline \multirow{2}{*}{ At harvest (Baseline) } & & 16.90 & 201.44 & 187.95 \\
\hline Day 7 & & & & \\
& Air & 16.79 & 208.27 & 203.45 \\
& 1-MCP & 15.08 & 211.53 & 200.08 \\
& Ethylene & 15.41 & 215.00 & 210.16 \\
\hline Day 15 & Air & 17.30 & 216.27 & 216.05 \\
& 1-MCP & 17.08 & 219.70 & 219.12 \\
& Ethylene & 14.39 & 219.04 & 222.43 \\
\hline Day 21 & Air & 7.22 & 253.23 & 250.80 \\
& 1-MCP & 7.77 & 269.73 & 274.29 \\
& Ethylene & 6.81 & 261.93 & 274.21 \\
\hline Day 30 & Air & 6.88 & 258.48 & 268.68 \\
& 1-MCP & 8.68 & 275.55 & 279.68 \\
& Ethylene & 7.14 & 273.50 & 299.49 \\
\hline LSD 0.05 (B x T S) & & 1.91 & 9.04 & 10.37 \\
\hline
\end{tabular}

Where B: Baseline; T: Treatment; S: sampling date. 